\title{
Rojas Paredes, Ramiro y Acuña, Álex; Chirif, Alberto (ed.). La historia jamás contada sobre la época del caucho. Dos testimonios indígenas. Lima: Instituto del Bien Común, 2015, 44 pp.
}

Publicado en junio de 2015, el breve libro La historia jamás contada sobre la época del caucho. Dos testimonios indígenas de Ramiro Rojas Paredes y Álex Acuña aporta una contribución notable a una bibliografía cada vez más amplia acerca de la época del caucho. Se sitúa, sin embargo, a contracorriente respecto de la mayoría de los textos sobre este tema, puesto que presenta la perspectiva indígena a través de «dos testimonios de primera mano» (p. 7).

En efecto, la mayoría de los trabajos sobre esa etapa socioeconómica (aun los que critican la violenta explotación esclavista llevada a cabo) presentan puntos de vista externos, dejando así de lado la interpretación de la viva voz de los que fueron las principales víctimas de un sistema de trabajo piramidal, en el que un inmenso número de trabajadores se dejaba literalmente la vida para el enriquecimiento de una élite compuesta por empresarios sin muchos escrúpulos.

El texto de Ramiro Rojas Paredes y Álex Acuña (editado por el antropólogo Alberto Chirif) rema en dirección contraria, proporcionando al lector el punto de vista indígena sobre dos acontecimientos clave: el desplazamiento forzoso de los trabajadores desde la región del Putumayo hacia la cuenca del río Ampiyacu y una rebelión indígena sofocada en la sangre en la sección conocida como Atenas.

Las dos historias son contadas por el anciano indígena del pueblo Murui Ramiro Coregoitsi Ificuense (apellidos que fue obligado a cambiar por los castellanos Rojas Paredes) a Álex Acuña, su único nieto, quien, según el expreso deseo del abuelo, «va a traducir al castellano y a quien con mucha confianza le voy a heredar esta historia para publicarla algún día y dar a conocer al país y el mundo lo que fue el más horrendo dolor que en mis entrañas llevo» (p. 19).

El primer texto colectado se titula «Narración autobiográfica de don Ramiro Coregoitsi Ificuense» y es un testimonio de las traumáticas experiencias vividas en los años de su infancia por el autor. Los abusos que los patrones mestizos solían perpetrar en contra de los trabajadores indígenas, la huida en busca de una mayor libertad son descritos con chocante sencillez a la vez que, al interior de estos relatos, se insertan elementos e imágenes de la cultura tradicional que aparecen como contrastes apacibles y a la vez enajenantes que en parte descolocan al lector.

El empleo del discurso en primera persona permite, sin embargo, establecer un sólido contacto con los destinatarios, abatir barreras invisibles, facilitar la 
identificación y compartir las experiencias. Ramiro Coregoitsi conduce a su nieto y a los lectores a través de los años de su infancia y pubertad (entre las décadas de 1920 y 1930 del siglo XX), caracterizados por los frecuentes traslados: desde Sabana, localidad situada a orillas del Cahuinarí, desde donde toda la familia escapa debido a los maltratos, hasta Santa Julia, y de aquí a El Encanto, una de las ex mayores secciones de la Peruvian Amazon Company (PAC) de Julio César Arana y que, en ese entonces, estaba al mando de Miguel Loayza, quien seguía explotando la mano de obra indígena.

En El Encanto, la familia de Ramiro, debido a la relación sentimental que unía a una de sus parientes con el patrón, goza de un trato mejor y de turnos de trabajo menos agotadores. Hasta que Loayza ordena que todos los indígenas del Encanto se desplacen a otro lugar, bajando por el Putumayo hasta su desembocadura en el Amazonas, y de allí surcando hacia el río Ampiyacu.

Ramiro confiesa que «en esa ocasión no comprendíamos por qué nos trasladaban de un momento a otro a otro destino» (p. 16). La razón tenía que ver con el intento de los peruanos de reconquistar la ciudad de Leticia (1932), cedida a los colombianos con la ratificación del Tratado Salomón-Lozano (1922-28). El temor a perder los territorios fronterizos, y con ellos a «sus» trabajadores, llevó Loayza a desplazar a un total de 6719 personas pertenecientes a los pueblos huitoto, bora, ocaina, muinane y andoque.

Ramiro relata así la fundación de la comunidad de Pucaurquillo, su bautismo, la imposición de los apellidos castellanos y la partida de Miguel Loayza, sobre quien se expresan tanto palabras de apreciación como de condena, develando la complejidad de las relaciones sociales en un contexto marcado por la desproporción en la distribución del poder.

En el segundo testimonio, titulado «La batalla sangrienta en Atenas», Ramiro Coregoitsi no relata una experiencia personal sino una rebelión acaecida en 1906, varios años antes de su nacimiento.

Primero el autor explica la situación de continuos maltratos que se llevaban a cabo en las propiedades de la Peruvian Amazon Company, y luego pasa a relatar el levantamiento encabezado por el jefe Gurai del clan Illobei, quien, exasperado de tanta violencia, planea una rebelión en contra del patrón. Gurai intenta convencer otros jefes indígenas para que se unan al motín, pero no lo consigue y, una vez desatada la batalla, es obligado a refugiarse en una gran maloca (una casa comunitaria tradicional) que había mandado construir no lejos de Atenas. Después de un breve sitio, los indígenas atrincherados en la maloca son aniquilados gracias al incendio que los caucheros prenden al techo de hojas de la inmensa casa. 
Este relato, a una primera lectura, parece una versión del conocido relato de la rebelión de Yarocamena, la historia del levantamiento de un jefe huitoto que mezcla la realidad histórica con el mito, cuya memoria se difundió no solo entre los huitoto sino también entre los demás pueblos que habitaban la misma zona, como Bora y Andoque (Pineda Camacho, 1988). Efectivamente, las dos historias comparten varios puntos de contacto, aunque en el testimonio de Ramiro Coregoitsi aparecen también elementos novedosos.

La rebelión de Gurai, tal y como la de Yarokamena, aun siendo intentos utópicos y habiendo fracasado, son dos ejemplos de resistencia efectiva a los abusos sufridos. Pero, como subraya el escritor Miguel Donayre (2002, p. 142), a la vez existieron prácticas de resistencia simbólica que se desarrollaron en distintos ámbitos: las reuniones para conversar, el consumo tradicional de coca y tabaco y el empleo de medios de comunicación como el manguaré serían también canales a través de los que se ha vehiculado la lucha cultural de los pueblos indígenas amazónicos. Donayre se interroga retóricamente si también narrar relatos e historias por los ancianos no sea una forma de sutil oposición al poder.

En este sentido, los textos del libro La historia jamás contada sobre la época del caucho de Ramiro Rojas Paredes se configuran como una acción práctica de resistencia simbólica, que permite una difusión que supera los límites de la acción inmediata y, al contrario, se prolonga en el eje de la diacronía.

Cabe mencionar, finalmente, la atenta síntesis introductoria del antropólogo Alberto Chirif y el interesante diccionario de regionalismos presente al final de la edición, que permite una comprensión cabal incluso a los lectores que tienen poca familiaridad con el ambiente amazónico. En esta perspectiva de comprensión total, se echan en falta algunas sugerencias bibliográficas.

Por último, destacamos el notable elemento gráfico y visual: el elegante marco de motivos geométricos que acompaña los márgenes de las páginas y, sobre todo, las varias fotografias que develan al lector el rostro del autor, Ramiro Coregoitsi Ificuense, su partida de bautismo, además del ambiente de las caucherías amazónicas y de un mapa de las propiedades de J.C. Arana.

Stefano Pau

Universidad de Cagliari (Italia) pau.stefano@ymail.com 


\section{REFERENCIAS BIBLIOGRÁFICAS}

Donayre Pinedo, Miguel (2002). Napoleón en la floresta. Iquitos: Tierra Nueva.

Pineda Camacho, Roberto (1988). Historia oral de una maloca sitiada en el Amazonas. Aspectos de la rebelión de Yarocamena contra la Casa Arana en 1917. Anuario Colombiano de historia social y de la Cultura, vol. 16-17, 163-82. Bogotá: Universidad Nacional de Colombia.

Resumen

El breve libro La historia jamás contada sobre la época del caucho. Dos testimonios indígenas aporta una contribución notable a una bibliografía cada vez más amplia acerca de la época del caucho, presentando un ejemplo de la perspectiva indígena sobre el tema.

Palabras clave: caucho, murui, testimonio oral. 